\title{
DAMPAK PROFITABILITAS, LIKUIDITAS DAN PENGUNGKAPAN ISLAMIC SOCIAL REPORTING TERHADAP RETURN SAHAM
}

\author{
Elsaputri Dyahayu Fatmawati ${ }^{1}$, Ari Kristin Prasetyoningrum², Dessy \\ Noor Farida ${ }^{3}$ \\ 1,2 3Universitas Islam Negeri Walisongo, Indonesia
}

$\triangle$ Corresponding Author:

Nama Penulis: Dessy Noor Farida

E-mail: dessy_nf@walisongo.ac.id

\begin{abstract}
Mining companies are capital-intensive industries a have high risks and their business activities have more physical and social environmental impacts compared to other business sectors. The purpose of this study was to analyze the effect of Return On Equity, Current Ratio, and Islamic Social Reporting disclosure to return stock. The samples used in this research are 13 mining companies listed in Indonesia Sharia Stock Index (ISSI) period 2014-2018 that are determined by purposive sampling. This research using the method of multiple linear regression analysis and hypothesis testing using program Eviews 9. The result of this research shows that in partial, Return On Equity and Current Ratio does not have a significant effects to return stock. While Islamic Social Reporting has significant effect to return Stock.
\end{abstract}

Key words: Return On Equity; Current Ratio; Islamic Social Reporting; Return Stock

\section{Abstrak}

Perusahaan pertambangan merupakan industri padat modal, memiliki risiko yang tinggi dan kegiatan usahanya memiliki dampak lingkungan dari segi fisik maupun sosial yang lebih banyak dibandingkan dengan sektor usaha lainnya. Tujuan penelitian ini adalah menganalisis pengaruh Return On Equity, Current Ratio dan Pengungkapan Islamic Social Reporting terhadap return saham. Sampel yang digunakan berjumlah 13 perusahaan pertambangan yang terdaftar di Indeks Saham Syariah Indonesia (ISSI) tahun 2014 hingga 2018 yang ditentukan berdasarkan purposive sampling. Penelitian ini menggunakan metode analisis regresi linear berganda data panel dengan aplikasi Eviews 9. Hasil penelitian menunjukkan bahwa Return On Equity tidak berpengaruh terhadap return saham, Current Ratio tidak berpengaruh terhadap return saham. Sedangkan, Islamic Social Reporting berpengaruh signifikan terhadap return saham.

Kata kunci: Return On Equity; Current Ratio; Islamic Social Reporting; Return Saham 


\section{PENDAHULUAN}

\section{Latar Belakang}

Perkembangan saham syariah Indonesia mengalami peningkatan dari tahun ke tahun, mengingat bahwa mayoritas agama yang ada di Indonesia adalah agama Islam. Hal ini sesuai dengan statistik perkembangan saham yang dilaporkan oleh Otoritas Jasa Keuangan. Pada tahun 2012, saham syariah yang ada berjumlah 321 pada periode kedua, hingga pada tahun 2018 telah mencapai 414 saham syariah pada periode kedua. Semakin banyaknya perusahaan yang menerbitkan saham syariah, akan membuat investor muslim semakin selektif dalam memilih perusahaan yang akan diberikan suntikan dana.

Investor tentunya akan memilih untuk menanamkan modalnya di sektor perusahaan yang cenderung mengalami keuntungan. Besar kecilnya tingkat pengembalian (return) tidak hanya terletak pada transaksi jual beli dalam pasar modal saja, namun juga dipengaruhi oleh keputusan investor dalam memilih jenis dan bidang usaha.

Perusahaan harus menampilkan informasi perusahaan dengan kinerja terbaik, dimana informasi diungkapkan dalam laporan keuangan yang handal (Budiyono \& Arum, 2020). Performa perusahaan yang bagus tentunya akan berdampak terhadap nilai perusahaan yang meningkat dan menyebabkan peningkatan return saham perusahaan tersebut. Oleh karena itu, untuk memprediksi return saham, investor melakukan pengukuran dan penilaian terhadap kinerja perusahaan (Rosmiati Tarmizi et al., 2018).

Investor yang sering menerapkan konsep berpikir cepat dan mengambil keputusan dengan cepat, menginginkan penggunaan rasio keuangan yang fleksibel dan sederhana namun dapat memberikan gambaran sesuai dengan yang mereka inginkan. Investor memilih untuk menggunakan rasio keuangan karena dapat membandingkan rasio satu perusahaan dengan perusahaan lain yang memiliki sektor sejenis dengan harapan dapat memberikan kemudahan dalam proses pengambilan keputusan (Fahmi, 2017).

Selain faktor keuangan terdapat faktor lain yang dapat menjadi faktor pertimbangan bagi investor yaitu faktor non keuangan. Hal ini dapat berupa informasi mengenai tanggung jawab sosial dalam laporan tahunan yang diterbitkan perusahaan sebagai bentuk komitmen perusahaan terhadap lingkungan, sosial dan masyarakat (Putra \& I Made Karya Utama, 2015). CSR adalah suatu tindakan yang dilakukan oleh perusahaan sebagai bentuk tanggung jawab mereka terhadap lingkungan maupun masyarakat sekitar dimana perusahaan tersebut berada (Rusmita, 2016).

Dalam lingkup syariah, tanggung jawab sosial perusahaan yang ada dikenal dengan nama Islamic Social Reporting (ISR). ISR merupakan suatu 
sistem yang digunakan untuk mengukur seberapa besar tanggung jawab sosial perusahaan terhadap masyarakat dan lingkungan yang berisi aspek material dan spiritual. Indeks ISR mengelompokkan indikator pengungkapan tanggung jawab sosial perusahaan menjadi enam tema, yaitu pembiayaan dan investasi, produk dan jasa, karyawan, masyarakat, lingkungan dan tata kelola perusahaan (Affandi \& Meta Nursita, 2019).

Penelitian yang dilakukan oleh Rosmiati Tarmizi et al. (2018), Wulandari, Purnomo, \& Murniati (2018), dan Rizal (2016) menyatakan bahwa ROE berpengaruh positif signifikan terhadap return saham. Namun, penelitian yang dilakukan Ani Rahmawati (2017) menyatakan bahwa ROE tidak berpengaruh terhadap return saham.

Penelitian yang dilakukan oleh Rosmiati Tarmizi et al. (2018), Wulandari, Purnomo, \& Murniati (2018) Current Ratio berpengaruh negatif dan signifikan terhadap return saham. Sedangkan, penelitian yang dilakukan oleh Rizal (2016) menyatakan Current Ratio berpengaruh positif terhadap return saham syariah. Namun, penelitian yang dilakukan oleh Fitriana et al., (2016) dan Nurmasari (2017) menyatakan bahwa Current Ratio tidak berpengaruh terhadap return saham.

Penelitian yang dilakukan oleh Rusmita (2016) menyatakan bahwa CSR berpengaruh tidak signifikan terhadap return saham. Sedangkan dalam penelitian yang dilakukan oleh I. B. G. W. Putra \& I Made Karya Utama (2015) menyatakan bahwa CSR berpengaruh signifikan terhadap return saham. Penelitian yang menggunakan ISR sebagai variabel untuk menguji return saham masih sangat jarang. Penelitian yang dilakukan oleh Harsono, (2015) menyatakan bahwa ISR berpengaruh negatif terhadap return saham syariah. Penelitian yang dilakukan oleh Mayasari (2019) menyatakan bahwa ISR berpengaruh tidak signifikan terhadap return saham syariah.

Berdasarkan research gap tersebut, peneliti ingin meneliti kembali pengaruh profitabilitas yang menggunakan ROE, likuiditas dengan menggunakan Current Ratio dan pengungkapan Islamic Social Reporting terhadap return saham dengan objek yaitu perusahaan pertambangan yang terdaftar di ISSI tahun 2014-2018.

\section{KAJIAN PUSTAKA}

\section{Return Saham}

Return merupakan hasil yang diperoleh dari kegiatan investasi. Return dapat berupa return realisasian (realized return) merupakan return yang telah terjadi, penghitungan menggunakan data historis. Dapat juga berupa return ekspektasian (expected return) merupakan return yang belum terjadi dan return yang diharapkan akan didapatkan oleh investor dimasa depan 
(Hartono, 2017). Ada dua jenis keuntungan yang dapat diperoleh yaitu dividen dan capital gain.

Dividen merupakan pembagian keuntungan yang diberikan perusahaan kepada pemegang saham yang berasal dari keuntungan yang dihasilkan perusahaan. Dividen diberikan setelah terdapat kesepakatan dalam RUPS, jika seorang pemegang saham ingin mendapatkan dividen maka ia harus memiliki saham tersebut dalam jangka waktu yang ditentukan oleh perusahaan.

Capital gain merupakan selisih antara harga beli dan harga jual, dimana hal ini terjadi karena adanya aktivitas perdagangan saham di pasar sekunder (Susilo, 2009). Jika harga saham sekarang $\left(\mathrm{P}_{\mathrm{t}}\right)$ lebih tinggi daripada harga saham periode sebelumnya $\left(\mathrm{P}_{\mathrm{t}-1}\right)$ maka akan terjadi keuntungan atau disebut capital gain dan return yang diterima bernilai positif. Sebaliknya jika harga saham sekarang $\left(\mathrm{P}_{\mathrm{t}}\right)$ lebih rendah daripada harga saham periode sebelumnya $\left(\mathrm{P}_{\mathrm{t}-1}\right)$ maka akan terjadi kerugian atau capital loss (Hartono, 2017).

Faktor yang mempengaruhi return sangat beragam dan hal itu menyebabkan return yang akan diterima oleh investor memiliki ketidakpastian. Hal ini dikarenakan, ketika berinvestasi memungkinkan untuk adanya kerugian maupun keuntungan yang berbeda dari yang diharapkan dengan kondisi masa depan yang tidak pasti. Sebagaimana hal ini dinyatakan dalam Al-Qur'an surat Al-A'raf ayat 188, yaitu:

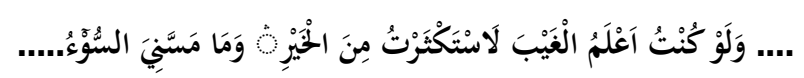

“... Dan sekiranya aku mengetahui yang ghaib, tentulah aku membuat kebajikan sebanyak-banyaknya dan aku tidak akan tertimpa kemudharatan ..."

Begitu juga di dalam Al-Qur'an surat Luqman ayat 34, dijelaskan sebagai berikut:

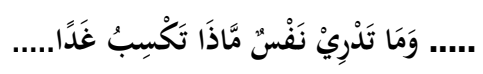

“... Dan tidak ada seorang pun yang dapat mengetahui (dengan pasti) apa yang akan dikerjakannya besok ...”

Berdasarkan kedua ayat Al-Qur'an tersebut dijelaskan tentang adanya ketidakpastian mengenai sesuatu di masa depan dan manusia tidak dapat mengetahui dengan pasti apa yang akan diusahakannya besok atau apa yang akan diperolehnya. Namun demikian, manusia diwajibkan untuk tetap berusaha dalam segala hal (Namjudin, 2011).

\section{Profitabilitas}

Rasio profitabilitas merupakan rasio yang digunakan untuk menilai kemampuan perusahaan dalam mencari keuntungan. Rasio ini memberikan 
gambaran tentang ukuran efektivitas manajemen suatu perusahaan. Hal ini ditunjukkan dengan laba yang dihasilkan dari kegiatan perusahaan dan pendapatan investasi (Kasmir, 2016).

\section{Return On Equity (ROE)}

Return on Equity (ROE) sering disebut sebagai hasil pengembalian ekuitas atau rentabilitas modal sendiri. ROE merupakan rasio yang digunakan untuk mengukur efisiensi modal yang digunakan oleh perusahaan. Rumus yang digunakan oleh ROE adalah laba bersih setelah pajak dan bunga dibagi dengan ekuitas. Semakin tinggi hasil dari perhitungan ROE maka hal itu akan menunjukkan bahwa posisi pemilik perusahaan semakin kuat (Kasmir, 2016).

ROE merupakan suatu perhitungan yang penting bagi perusahaan. Ketika suatu perusahaan melaporkan ROE yang tinggi dan konsisten, maka perusahaan tersebut menunjukkan bahwa ia memiliki keunggulan untuk bertahan terhadap persaingan dalam jangka waktu yang lama. Jika perusahaan memperoleh laba yang tinggi, maka permintaan saham akan meningkat dan hal itu akan menyebabkan kenaikan harga saham. Ketika harga saham meningkat hal itu akan sejalan dengan return saham yang meningkat (Desiana \& Titin Hartini, 2014).

\section{Likuiditas}

Rasio likuiditas dapat mengukur kemampuan perusahaan dalam memenuhi kewajiban jangka pendeknya. Rasio ini penting karena jika terjadi kegagalan dalam membayar kewajiban hal itu akan menyebabkan kebangkrutan perusahaan. Rasio ini mengukur pada kemampuan likuiditas jangka pendek perusahaan dengan melihat aktiva lancar perusahaan relatif terhadap kewajiban perusahaan (Fahmi, 2017).

\section{Current Ratio (CR)}

Current Ratio atau dapat disebut dengan rasio lancar merupakan salah satu dari bagian rasio likuiditas. Rasio ini mampu menunjukkan kemampuan perusahaan dalam memenuhi kewajiban lancarnya menggunakan aktiva lancar yang dimiliki. Current Ratio dapat pula dianggap sebagai rasio untuk mengukur tingkat keamanan perusahaan (margin of safety) (Kasmir, 2016)

Jika perhitungan Current Ratio menunjukkan hasil yang tinggi hal itu akan menunjukkan bahwa perusahaan memiliki kas yang berlebihan dibandingkan kebutuhan atau dapat disebabkan oleh banyaknya unsur aktiva lancar yang rendah likuiditasnya, seperti persediaan. Current Ratio yang tinggi dianggap kurang baik bagi investor. Karena perusahaan kurang mampu memanfaatkan dana yang ada dengan efektif. Namun, Current Ratio 
yang rendah juga tidak baik, tetapi hal itu menunjukkan bahwa manajemen mampu memanfaatkan dana dengan efektif (Jumingan, 2014).

Alasan digunakannya Current Ratio sebagai ukuran likuiditas karena kemampuannya dalam mengukur beberapa hal, yaitu kemampuan dalam memenuhi kewajiban lancar, sebagai penyangga kerugian dan sebagai cadangan dana lancar (Fahmi, 2017).

\section{Islamic Social Reporting (ISR)}

Indeks ISR pertama kali dikenalkan oleh Ros Haniffa pada tahun 2002 dalam tulisannya yang berjudul "Social Reporting Disclosure: An Islamic Perspective". Haniffa (2002) menjelaskan mengenai lima tema yang menjadi dasar pengungkapan ISR yaitu keuangan dan investasi, produk dan jasa, karyawan, masyarakat, dan lingkungan hidup. Kemudian pada tahun 2009, Othman et al mengembangkan penelitian Haniffa dengan menambahkan satu tema pengungkapan yaitu tata kelola perusahaan. Kemudian indeks tersebut ditetapkan oleh AAOIFI (Accounting and Auditing Organization for Islamic Financial Institutions).

Konsep pertanggungjawaban lingkungan perusahaan sering dianggap sebagai cara untuk memperbaiki citra dan reputasi perusahaan dengan memberikan gambaran bahwa perusahaan tersebut bertanggung jawab terhadap lingkungan. Akan tetapi, selama beberapa tahun ini permasalahan lingkungan sering kali terjadi. Hal ini menunjukkan bahwa masalah lingkungan pada perusahaan belum dapat terselesaikan karena kurang tepatnya pendekatan lingkungan yang dilakukan perusahaan (Farida, 2019).

Hal ini sesuai dengan firman Allah dalam Al-Qur'an Surat Al-Baqarah ayat 11-12, sebagai berikut:
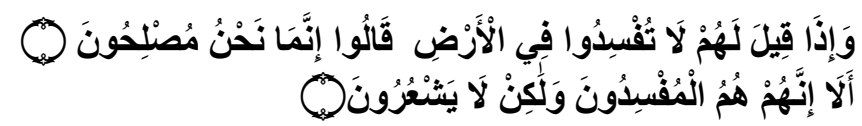

"Dan apabila dikatakan kepada mereka, "Janganlah berbuat kerusakan di bumi!" Mereka menjawab, "Sesungguhnya kami justru orang-orang yang melakukan perbaikan". Ingatlah sesungguhnya merekalah yang berbuat kerusakan, tetapi mereka tidak menyadari"

Allah juga menjelaskan firman-Nya dalam Al-Qur'an Surat Al-A'raf ayat 56, yaitu:

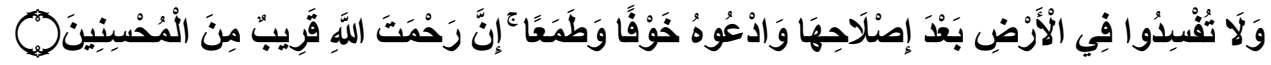

"Dan janganlah kamu membuat kerusakan di bumi setelah (diciptakan) dengan baik. Berdoalah kepada-Nya dengan rasa takut dan penuh harap. Sesungguhnya rahmat Allah sangat dekat kepada orang-orang yang berbuat kebaikan."

Dari kedua ayat diatas telah dijelaskan bahwa manusia dilarang untuk melakukan kerusakan terhadap bumi yang telah Allah ciptakan dengan baik. 
Manusia bertanggung jawab untuk menjaga dan memelihara kelestarian lingkungan bumi dan ciptaan Allah.

Ada hal yang terpenting dalam tanggung jawab sosial perusahaan menurut perspektif Islam, yaitu akuntabilitas. Akuntabilitas menjelaskan adanya hubungan antara individu, perusahaan dan Allah SWT. Hal ini dikarenakan semua sumber daya yang ada di muka bumi merupakan milik Allah, sebagai manusia harus mempertanggungjawabkan kepada-Nya. Oleh karena itu, laporan pertanggung jawaban yang dibuat bukan hanya ditujukan untuk keuntungan finansial dan kepentingan orang tertentu saja, tetapi juga sebagai bentuk tanggung jawab kepada Allah (Rahayu \& Ari Dwi Cahyati, 2015).

Diharapkan investor dapat mempertimbangkan berbagai informasi yang dikeluarkan oleh perusahaan berupa laporan keuangan dan informasi mengenai pengungkapan tanggung jawab sosial. Apabila informasi pengungkapan tanggung jawab sosial menjadi bahan pertimbangan oleh investor dalam pengambilan keputusan yang diikuti dengan kenaikan pembelian saham perusahaan sehingga terjadi kenaikan harga saham yang melebihi return yang diekspektasikan oleh investor, sehingga akhirnya informasi tanggung jawab sosial merupakan informasi yang memiliki nilai tambah bagi investor (Arnel \& Astuti Yuli Setyani, 2018).

\section{HIPOTESIS}

\section{Pengaruh Return On Equity Terhadap Return Saham}

ROE merupakan salah satu rasio yang menjadi bagian dari rasio profitabilitas yang digunakan untuk mengetahui tingkat pengembalian (return) investasi yang ditanamkan oleh investor. Rasio ini dianggap paling tepat dalam kaitannya dengan return saham, karena akun modal saham termasuk ke dalam bagian jumlah ekuitas.

ROE merupakan ukuran rasio profitabilitas yang dapat dilihat dari sisi pemegang saham, semakin tinggi ROE yang didapatkan hal itu menggambarkan bahwa perusahaan tersebut dapat memberikan peluang mengenai pengembalian (return) yang besar bagi investor (Wardani, Hermiyetti, \& Muhammad Yusuf, 2017).

Penelitian yang dilakukan oleh Rosmiati Tarmizi et al. (2018), penelitian Wulandari et al. (2018) menyatakan bahwa ROE berpengaruh terhadap return saham.

Berdasarkan uraian tersebut, maka hipotesis yang digunakan dalam penelitian ini yaitu:

$\mathrm{H}_{1}$ : Return on Equity berpengaruh terhadap return saham

\section{Pengaruh Current Ratio Terhadap Return Saham}

Current Ratio merupakan salah satu rasio dari beberapa macam rasio yang dimiliki oleh rasio likuiditas. Current Ratio menggambarkan 
kemampuan perusahaan dalam memenuhi kewajiban yang akan jatuh tempo. Hasil dari perhitungan Current Ratio yang tinggi akan mengindikasikan bahwa investor akan mendapat return yang tinggi jika perusahaan mampu memenuhi kewajiban jangka pendeknya (I. M. G. D. Putra \& I Made Dana, 2016).

Penelitian yang dilakukan oleh Ulupui (2009), Yuliantari W. \& Sujana (2014), Rizal, (2016), Parwati \& Sudiartha (2016) bahwa Current Ratio berpengaruh terhadap return saham.

Berdasarkan paparan diatas maka hipotesis yang digunakan dalam penelitian ini adalah sebagai berikut:

$\mathrm{H}_{2}$ : Current Ratio berpengaruh terhadap return saham

\section{Pengaruh Islamic Social Reporting Terhadap Return Saham}

Pengungkapan tanggung jawab sosial menurut Islam menginginkan pelaporan yang tidak hanya memuaskan aspek material saja namun juga spiritual. Oleh sebab itu dalam kerangka konseptual pertanggung jawaban sosial berdasarkan prinsip syariah yang dikembangkan akan menjadi jawaban yang komprehensif. Karena didalamnya terdapat aspek material, moral dan spiritual yang seimbang diantara ketiganya (Haniffa, 2002).

Perusahaan yang berusaha mengungkapkan tanggung jawab sosialnya menurut indeks ISR, akan meningkatkan kepercayaan dan menarik investor muslim untuk berinvestasi di perusahaan tersebut. Hal ini akan menaikkan permintaan saham, kemudian harga saham akan meningkat. Seiring dengan kenaikan harga saham maka akan diikuti dengan kenaikan return yang akan diperoleh investor. Semakin tinggi tingkat pengungkapan ISR maka akan meningkatkan return bagi investor (Harsono, 2015).

Penelitian yang dilakukan oleh Budi, Tomas S.W (2010), Atiqah (2016), dan I. B. G. W. Putra \& I Made Karya Utama (2015) menyatakan bahwa CSR berpengaruh terhadap return saham

Berdasarakan paparan penjelasan diatas, maka hipotesis yang digunakan dalam penelitian ini adalah:

$\mathrm{H}_{3}$ : Pengungkapan Islamic Social Reporting berpengaruh terhadap return saham

\section{METODE}

\section{Jenis dan Sumber Data}

Penelitian ini merupakan penelitian kuantitatif dengan metode regresi linier berganda data panel sebagai teknik analisis. Data yang digunakan merupakan data sekunder. Data yang digunakan adalah laporan keuangan dan annual report perusahaan pertambangan yang terdaftar di Indeks Saham 
Syariah Indonesia tahun 2014-2018. Data yang digunakan bersumber dari website BEI dan website perusahaan terkait.

\section{Populasi dan Sampel}

Populasi yang digunakan dalam penelitian ini adalah perusahaan pertambangan yang terdaftar di Indeks Saham Syariah Indonesia tahun 2014-2018. Jumlah perusahaan yang terdaftar adalah 36 perusahaan. Pemilihan sampel penelitian dipilih dengan metode purposive sampling menggunakan beberapa syarat tertentu. Syarat yang digunakan sebagai berikut:

1. Perusahaan pertambangan yang terdaftar secara konsisten di Indeks Saham Syariah Indonesia (ISSI) mulai tahun 2014 sampai tahun 2018.

2. Perusahaan yang melaporkan laporan keuangan tahunan yang telah diaudit selama tahun 2014 hingga 2018.

3. Perusahaan melaporkan kegiatan tanggung jawab sosial yang tertera dalam Annual Report selama tahun 2014 hingga 2018.

4. Perusahaan pertambangan yang mengalami laba positif pada akhir periode pengamatan.

5. Perusahaan pertambangan yang mengalami kenaikan return.

Dari syarat tersebut, terdapat 13 perusahaan pertambangan yang sesuai untuk digunakan dalam penelitian kali ini.

\section{Definisi Operasional Variabel Penelitian}

Return On Equity merupakan rasio yang dapat mengukur keefektifan modal yang digunakan oleh perusahaan. Rumus yang digunakan yaitu :

$$
\text { ROE }=\frac{\text { Laba Setelah Pajak }}{\text { Ekuitas }}
$$

Current Ratio merupakan rasio yang dapat mengukur kemampuan perusahaan dalam melunasi kewajiban lancarnya dengan aktiva lancar yang dimiliki. Maka rumus yang digunakan adalah:

$$
\text { Current Ratio }=\frac{\text { Aktiva Lancar }}{\text { Kewajiban Lancar }}
$$

Pengungkapan mengenai ISR dibagi menjadi enam tema pengungkapan yang berbeda tiap tema memiliki beberapa macam poin pengungkapan yang jika dijumlahkan berjumlah 42 poin pengungkapan. Penilaian ISR dilakukan dengan metode scoring. Berikut rumus yang digunakan :

$$
\text { ISR }=\frac{\text { Jumlah pengungkapan }}{\text { Total Pengungkapan }}
$$


Variabel dependen dalam penelitian ini adalah return saham. Yang digunakan adalah return realisasi. Rumus yang digunakan adalah :

Return Saham $=\frac{\mathrm{Pi}(\mathrm{t})-\mathrm{Pi}(\mathrm{t}-1)}{\mathrm{Pi}(\mathrm{t}-1)}$

\section{HASIL DAN PEMBAHASAN}

\section{Analisis Data}

\section{Estimasi Model Regresi Data Panel}

Regresi linier berganda data panel menggunakan Eviews 9 terdiri dari tiga model yang berbeda, yaitu Common Effect Model (CEM), Fixed Effect Model (FEM) dan Random Effect Model (REM). Untuk memilih model yang sesuai dengan data penelitian diperlukan pengujian lebih lanjut.

\section{Uji Lagrange Multiplier}

Uji Lagrange Multiplier (Uji LM) digunakan untuk menguji model yang lebih baik antara Common Effect Model (CEM) dengan Random Effect Model (REM). Dalam uji ini pemilihan model didasarkan pada nilai distribusi statistik Breusch Pagan. Jika nilai probabilitasnya $<5 \%$ maka Random Effect Model (REM) lebih baik. Apabila nilai probabilitasnya > 5\% maka Common Effect Model (CEM) yang lebih baik (Widarjono, 2018). Berikut ini adalah hasil dari Uji LM:

Tabel 1. Uji Lagrange Multiplier

\begin{tabular}{cccc}
\hline & \multicolumn{3}{c}{ Test Hypothesis } \\
\hline & Cross-section & Time & Both \\
Breusch-Pagan & 4.638761 & 48.39340 & 53.03216 \\
& $(0.0313)$ & $(0.0000)$ & $(0.0000)$ \\
\hline
\end{tabular}

\section{Sumber: data yang diolah, 2020}

Berdasarkan hasil Uji LM pada Tabel 1. diketahui bahwa nilai crosssection Breusch-Pagan sebesar 0,0313 dimana nilai tersebut lebih kecil daripada 0,05. Maka dapat diambil kesimpulan bahwa Random Effect Model yang terpilih berdasarkan Uji LM.

\section{Uji Hausman}

Uji Hausman merupakan teknik pengujian yang membandingkan Fixed Effect Model (FEM) dengan Random Effect Model (REM). Pengujian ini melihat nilai probabilitas dari distribusi statistik chi-square. Jika nilai probabilitas > 0,05 maka model mengikuti Random Effect Model (REM). Jika nilai probabilitas < 0,05 maka model mengikuti Fixed Effect Model (FEM) (Widarjono, 2018). Berikut ini adalah hasil Uji Hausman: 
Elsaputri Dyahayu Fatmawati : Dampak Profitabilitas, Likuiditas dan Pengungkapan ISR

\begin{tabular}{lccc}
\multicolumn{4}{c}{ Tabel 2. Uji Hausman } \\
\hline $\begin{array}{l}\text { Correlated Random Effects - Hausman Test } \\
\text { Test cross-section random effects } \\
\text { Test Summary }\end{array}$ & Chi-Sq. Statistic Chi-Sq. d.f. & Prob. \\
\hline Cross-section random & 3.212208 & 3 & 0.3600 \\
\hline
\end{tabular}

Sumber: data yang diolah, 2020

Berdasarkan hasil Uji Hausman pada Tabel 2. yang telah dilakukan maka dapat diketahui nilai Chi-square adalah 0,3600 dimana nilai tersebut lebih besar daripada 0,05. Maka berdasarkan hipotesis yang ada, dengan hasil nilai tersebut menyatakan bahwa model yang terpilih dengan Uji Hausman adalah Random Effect Model.

Berdasarkan kedua uji yang telah dilakukan, keduanya menyatakan bahwa Random Effect Model yang terpilih sebagai model regresi dalam penelitian kali ini.

\section{Uji Asumsi Klasik} Uji Normalitas

Uji normalitas dapat dilakukan dengan histogram dan uji Jarque-Bera. Jika nilai probabilitas Jarque-Bera lebih besar dari 5\% maka data terdistribusi normal. Jika nilai probabilitas Jarque-Bera lebih kecil dari 5\% maka data tidak terdistribusi normal (Winarno, 2017). Berikut hasil uji normalitas:

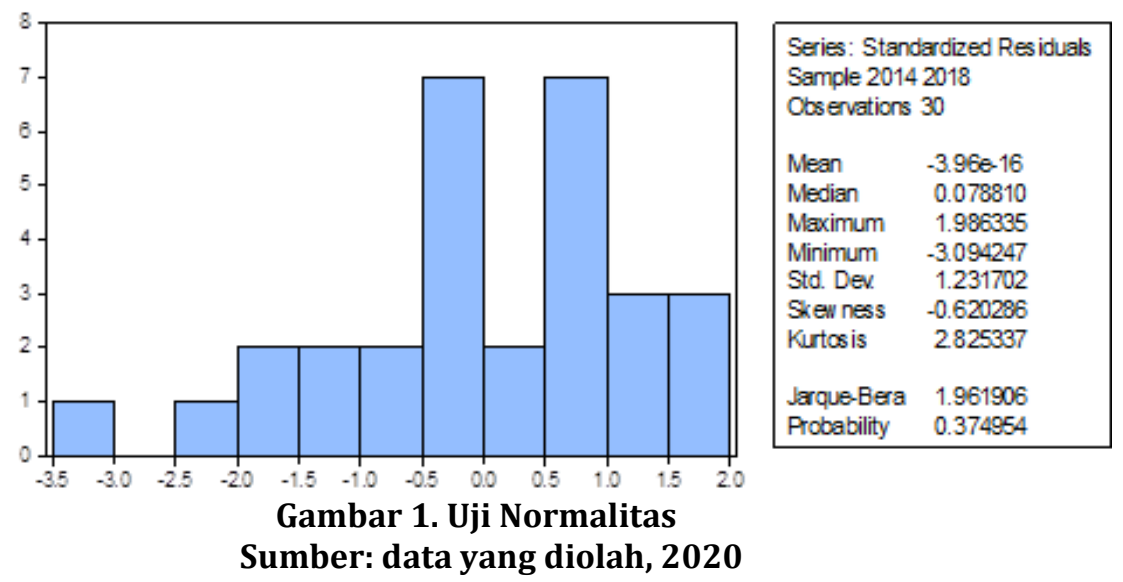

Berdasarkan Gambar 1. nilai Jarque-Bera sebesar 1,961906 dengan probabilitas sebesar 0,374954. Dimana jika dibandingkan dengan nilai signifikansi 0,05 maka nilai probabilitas yang dihasilkan lebih besar dari nilai signifikansi. Maka dapat disimpulkan bahwa data terdistribusi normal. 


\section{Uji Multikolinieritas}

Gejala multikolinieritas dalam model regresi yaitu ditandai dengan model yang memiliki nilai VIF (Variance Inflation Factors) diatas 10. Jika antar variabel independen memiliki korelasi yang tinggi, yaitu diatas 10 maka terdapat masalah multikolinieritas dalam model regresi (Sanusi, 2011). Berikut hasil uji multikolinieritas:

Berdasarkan Tabel 3. dapat dilihat bahwa tidak ada nilai Centered VIF dari masing-masing variabel independen yang menunjukkan nilai lebih dari 10. Sehingga dapat dinyatakan bahwa model regresi tidak memiliki masalah multikolinieritas.

\section{Uji Heterokedastisitas}

Uji ini menggunakan nilai absolut residual sebagai variabel dependennya. Jika nilai probabilitas $>5 \%$ maka tidak terjadi heterokedastisitas (Widarjono, 2018). Berikut hasil uji heterokedastisitas:

Berdasarkan Tabel 4. dapat diketahui bahwa nilai probabilitas ROE adalah 0,5376, nilai probabilitas CR sebesar 0,4337, dan nilai probabilitas ISR adalah 0,8683. Dari keseluruhan variabel independen didapatkan bahwa nilai probabilitas berada diatas 0,05 . Hal itu menandakan bahwa tidak terjadi gejala heterokedastisitas.

\section{Uji Autokorelasi}

Autokorelasi diuji dengan menggunakan Uji Durbin-Watson (Widarjono, 2018). Dengan uji ini telah ditentukan aturan mengenai pengambilan keputusan. Tabel 5 menunjukkan pengambilan keputusan Durbin-Watson. Tabel 6 menunjukkan nilai hasil uji autokorelasi. Berdasarkan nilai DurbinWatson yang diperoleh dari pengolahan data yang dilakukan didapatkan hasil 2,229401. Dari tabel tersebut didapat bahwa nilai d sebesar 1,5035 dan nilai du sebesar 1,6960, kemudian mencari nilai $4-1,6960$ adalah 2,3040. Sehingga dari uji ini didapatkan hasil 1,6960<2,229401<2,3040. Berdasarkan tabel pengambilan keputusan Durbin-Watson bahwa tidak terjadi autokorelasi dalam model regresi ini.

\section{Tabel 3. Uji Multikolinieritas}

Variance Inflation Factors

Included observations: 65

\begin{tabular}{cccc}
\hline Variable & $\begin{array}{c}\text { Coefficient } \\
\text { Variance }\end{array}$ & $\begin{array}{c}\text { Uncentered } \\
\text { VIF }\end{array}$ & $\begin{array}{c}\text { Centered } \\
\text { VIF }\end{array}$ \\
\hline ROE & 0.476805 & 1.863121 & 1.052883 \\
CR & 0.004909 & 4.424830 & 1.065368 \\
ISR & 1.138071 & 67.54607 & 1.049858 \\
\hline
\end{tabular}

Sumber: data yang diolah, 2020 
Elsaputri Dyahayu Fatmawati : Dampak Profitabilitas, Likuiditas dan Pengungkapan ISR

Dependent Variable: RESABS

Tabel 4. Uji Heterokedastisitas

\begin{tabular}{ccccc}
\hline Variable & Coeff & Std. Error & t-Statistic & Prob. \\
\hline C & 0.5852 & 1.3391 & 0.4370 & 0.6657 \\
ROE & -0.6253 & 1.0011 & -0.6247 & 0.5376 \\
CR & 0.0881 & 0.1108 & 0.7951 & 0.4337 \\
ISR & 0.3756 & 1.8799 & 0.1997 & 0.8432
\end{tabular}

Sumber: data yang diolah, 2020

Tabel 5. Pengambilan Keputusan Durbin-Watson

\begin{tabular}{cl}
\hline Nilai statistik $\mathrm{d}$ & \multicolumn{1}{c}{ Hasil } \\
\hline $0<\mathrm{d}<\mathrm{d}_{\mathrm{l}}$ & Ada autokorelasi positif \\
$\mathrm{d}_{\mathrm{l}}<\mathrm{d}<\mathrm{d}_{\mathrm{u}}$ & Tidak ada keputusan \\
$\mathrm{d}_{\mathrm{u}}<\mathrm{d}<4-\mathrm{d}_{\mathrm{u}}$ & Tidak ada autokorelasi \\
$4-\mathrm{d}_{\mathrm{u}}<\mathrm{d}<4-\mathrm{d}_{\mathrm{l}}$ & Tidak ada keputusan \\
$4-\mathrm{d}_{\mathrm{l}}<\mathrm{d}<4$ & Ada autokorelasi negatif \\
\hline
\end{tabular}

Sumber: Agus Widarjono

Tabel 6. Uji Autokorelasi

\begin{tabular}{ll}
\hline Durbin-Watson stat & 2.229401 \\
\hline
\end{tabular}

Sumber: data yang diolah, 2020

\section{Pengujian Hipotesis}

Hasil Uji Hipotesis dijelaskan pada Tabel 7. Berikut ini:

Tabel 7. Hasil Output Pengujian Hipotesis

Dependent Variable: RS

Method: Panel EGLS (Cross-section random effects)

Sample: 20142018

Periods included: 5

Cross-sections included: 13

Total panel (balanced) observations: 65

Swamy and Arora estimator of component variances

\begin{tabular}{lrrrr}
\multicolumn{1}{c}{ Variable } & Coefficient & Std. Error & t-Statistic & Prob. \\
C & -1.608533 & 0.754843 & -2.130950 & 0.0371 \\
ROE & 0.260759 & 0.737489 & 0.353576 & 0.7249 \\
CR & 0.072092 & 0.074832 & 0.963382 & 0.3392 \\
ISR & 2.321995 & 1.139383 & 2.037940 & 0.0459 \\
\hline R-squared & 0.103951 & Mean dependent var & 0.147969 \\
Adjusted R-squared & 0.059883 & S.D. dependent var & 0.731191 \\
S.E. of regression & 0.708960 & Sum squared resid & 30.66006 \\
F-statistic & 2.358889 & Durbin-Watson stat & 3.241569 \\
Prob(F-statistic) & 0.080329 & & \\
\hline
\end{tabular}

Sumber: data yang diolah, 2020 


\section{Uji Simultan (Uji F)}

Nilai statistik F sebesar 2,358889 dengan probabilitas sebesar 0,080329 yang hasilnya lebih tinggi daripada signifikansi sebesar 0,05. Maka dapat disimpulkan bahwa seluruh variabel independen yaitu ROE, CR dan ISR secara simultan tidak berpengaruh signifikan terhadap variabel dependen yaitu return saham.

\section{Uji Parsial (Uji t)}

Nilai t-statistik yang diperoleh dari ROE dalam penelitian ini sebesar 0,353576 dengan probabilitas 0,7249 yang memiliki nilai lebih tinggi daripada nilai signifikansi sebesar 0,05. Sehingga, $\mathrm{H}_{1}$ ditolak karena ROE tidak berpengaruh terhadap return saham.

Nilai t-statistik yang diperoleh dari CR dalam penelitian ini sebesar 0,963382 dengan probabilitas sebesar 0,3392 yang memiliki nilai lebih tinggi daripada nilai signifikansi sebesar 0,05 . Sehingga, $\mathrm{H}_{2}$ ditolak karena CR tidak berpengaruh terhadap return saham.

Nilai t-statistik yang diperoleh dari variabel ISR dalam penelitian ini adalah 2,037940 dengan probabilitas sebesar 0,0459 yang memiliki nilai lebih rendah daripada nilai signifikansi sebesar 0,05 . Sehingga, $\mathrm{H}_{3}$ diterima karena ISR berpengaruh signifikan terhadap return saham.

\section{Koefisien Determinasi ( $\left.\mathbf{R}^{2}\right)$}

Hasil Adjusted R-squared sebesar 0,059883 yang berarti bahwa ROE, CR dan ISR memiliki pengaruh terhadap return saham sebesar 5,98\%. Sedangkan sisanya sebesar 94,02\% dijelaskan oleh faktor lain di luar variabel independen dalam penelitian.

\section{Pembahasan}

\section{Pengaruh Return On Equity Terhadap Return Saham}

Return on Equity merupakan salah satu dari berbagai macam rasio yang termasuk dalam profitabilitas. ROE sering disebut sebagai hasil pengembalian ekuitas atau rentabilitas modal sendiri. ROE merupakan rasio yang digunakan untuk mengukur efisiensi modal yang digunakan oleh perusahaan. Rumus yang digunakan oleh ROE adalah laba bersih setelah pajak dan bunga dibagi dengan ekuitas. Semakin tinggi hasil dari perhitungan ROE maka hal itu akan menunjukkan bahwa posisi pemilik perusahaan semakin kuat (Kasmir, 2016)

Berdasarkan analisis data dan pengujian hipotesis yang telah dilakukan, dapat diketahui bahwa Return On Equity (ROE) secara parsial tidak berpengaruh terhadap return saham perusahaan pertambangan yang terdaftar di Indeks Saham Syariah Indonesia (ISSI) selama 2014-2018. Hal ini 
dikarenakan nilai rata-rata ROE perusahaan pertambangan pada tahun penelitian sebesar 0,114 atau 11,4\%. Angka tersebut berada di bawah ratarata industri yaitu 40\%. Hal itu menunjukkan bahwa perusahaan kurang mampu menggunakan modal perusahaan dengan efisien. Dikarenakan nilai ekuitas lebih tinggi daripada laba yang dihasilkan. Sehingga hal ini akan memberikan sinyal kepada investor bahwa perusahaan kurang mampu memberikan return yang besar kepada investor.

Hasil penelitian ini sesuai dengan penelitian yang dilakukan telah dilakukan oleh Rahmawati (2017), Purnamasari (2017) dan Priyonoto, Wibowo, \& Diarsyad (2018) yang menyatakan bahwa ROE tidak berpengaruh terhadap return saham.

\section{Pengaruh Current Ratio Terhadap Return Saham}

Current Ratio atau dapat disebut dengan rasio lancar merupakan salah satu dari bagian rasio likuiditas. Rasio ini mampu menunjukkan kemampuan perusahaan dalam memenuhi kewajiban lancarnya menggunakan aktiva lancar yang dimiliki. Current Ratio dapat pula dianggap sebagai rasio untuk mengukur tingkat keamanan perusahaan (margin of safety) (Kasmir, 2016).

Berdasarkan analisis data dan pengujian hipotesis yang telah dilakukan, dapat diketahui bahwa Current Ratio (CR) secara parsial tidak berpengaruh signifikan terhadap return saham perusahaan pertambangan yang terdaftar di Indeks Saham Syariah Indonesia (ISSI) selama 2014-2018. Hal ini dikarenakan karena nilai rata-rata CR yang tinggi sebesar 2,300 atau 230\% dimana angka tersebut melebihi rata-rata industri yang telah ditetapkan yaitu 200\%. Dengan nilai CR yang tinggi, hal itu menunjukkan bahwa perusahaan memiliki aktiva lancar yang berlebihan dibandingkan kebutuhan. CR yang tinggi dapat memberikan gambaran bahwa aktiva lancar yang dimiliki oleh perusahaan tidak dioptimalkan dengan baik. Sehingga hal itu akan mengurangi minat investor dalam menanamkan modalnya dan akan berdampak pada menurunnya harga saham yang kemudian akan berimbas pada penurunan return saham.

Tidak berpengaruhnya CR terhadap return saham dapat diakibatkan juga dengan keyakinan para investor bahwa perusahaan pertambangan mampu membayar kewajiban jangka pendeknya. Dikarenakan perusahaan pertambangan merupakan industri yang tangguh meskipun selama 2014 hingga 2018, sektor ini mengalami penurunan namun mereka masih bertahan. Sehingga investor cenderung tidak melihat CR ketika akan melakukan investasi dan pada akhirnya tidak membawa pengaruh terhadap return saham.

Hasil penelitian ini sejalan dengan penelitian yang dilakukan oleh Thrisye \& Simu, (2013), Fitriana et al. (2016) dan Nurmasari (2017) yang 
menyatakan bahwa Current Ratio tidak berpengaruh secara signifikan terhadap return saham.

\section{Pengaruh Islamic Social Reporting Terhadap Return Saham}

ISR adalah bentuk tanggung jawab perusahaan terhadap lingkungan baik kepedulian sosial maupun tanggung jawab lingkungan yang tidak mengabaikan kemampuan perusahaan yang sesuai dengan prinsip Islam. ISR memiliki dua tujuan utama yaitu sebagai akuntabilitas kepada Allah SWT dan masyarakat dan meningkatkan transparansi kegiatan bisnis yang dilakukan perusahaan dengan memberikan informasi yang relevan dengan kebutuhan spiritual para pengguna laporan yang muslim. (Prasetyoningrum, 2018)

Perusahaan yang berusaha mengungkapkan tanggung jawab sosialnya menurut indeks ISR maka hal itu akan meningkatkan kepercayaan dan menarik investor muslim untuk menanamkan dananya di perusahaan tersebut. Hal ini akan menaikkan permintaan atas saham, kemudian harga saham akan meningkat. Seiring dengan kenaikan harga saham maka akan diikuti dengan kenaikan return yang akan diperoleh investor. Semakin tinggi tingkat pengungkapan ISR maka akan meningkatkan return bagi investor. (Harsono, 2015)

Berdasarkan analisis data dan pengujian hipotesis yang telah dilakukan, dapat diketahui bahwa Islamic Social Reporting (ISR) secara parsial berpengaruh positif dan signifikan terhadap return saham perusahaan pertambangan yang terdaftar di Indeks Saham Syariah Indonesia (ISSI) selama 2014-2018. Hal ini menunjukkan bahwa dengan adanya pengungkapan kegiatan tanggung jawab sosial perusahaan berupa ISR memberikan sinyal yang positif bagi para investor, terlebih lagi para investor muslim untuk menanamkan dananya di perusahaan yang melakukan kegiatan tanggung jawab sosial.

Hasil penelitian ini sesuai dengan penelitian yang dilakukan oleh A.A. Istri Raisa Wulandari dengan I Gusti Ayu Made Asri Dwija Putri (2014), I. B. G. W. Putra \& I Made Karya Utama (2015), dan Sulistiyowati (2018) yang menyatakan bahwa CSR berpengaruh positif terhadap return saham.

\section{KESIMPULAN}

Berdasarkan hasil penelitian dan pembahasan yang telah dilakukan, dapat ditarik kesimpulan bahwa Return On Equity $\left(\mathrm{X}_{1}\right)$ tidak berpengaruh terhadap return saham pada perusahaan pertambangan yang terdaftar di Indeks Saham Syariah Indonesia (ISSI) periode 2014-2018. Berdasarkan nilai signifikansi Uji t sebesar 0,7249 yang mana lebih besar dari pada 0,05 (5\%). Karena nilai ROE tinggi menunjukkan bahwa perusahaan kurang mampu menggunakan modal perusahaan dengan efisien sehingga menurunkan minat 
investor, kemudian berakibat pada menurunnya harga saham dan akan diikuti dengan menurunnya return saham.

Current Ratio $\left(\mathrm{X}_{2}\right)$ tidak berpengaruh terhadap return saham pada perusahaan pertambangan yang terdaftar di Indeks Saham Syariah Indonesia (ISSI) karena nilai CR yang tinggi sebesar 0,3392 menggambarkan perusahaan memiliki aktiva lancar yang kurang dimanfaatkan dan dianggap mampu untuk melunasi kewajiban jangka pendeknya, sehingga CR kurang diperhatikan oleh investor sebagai pedoman dalam pengambilan keputusan investasi.

Islamic Social Reporting $\left(\mathrm{X}_{3}\right)$ secara signifikan berpengaruh positif terhadap return saham pada perusahaan pertambangan, berdasarkan pada nilai signifikansi Uji t sebesar 0,0459 yang mana nilai tersebut lebih rendah dari nilai signifikansi uji t yaitu 0,05. Dengan adanya pengungkapan kegiatan tanggung jawab sosial perusahaan berupa ISR memberikan gambaran kepada investor mengenai peranan perusahaan tersebut kepada masyarakat dan lingkungan.

\section{SARAN}

Diharapkan bagi peneliti selanjutnya yang akan meneliti dengan topik yang sama dapat menggunakan variabel lain yang belum digunakan dalam penelitian dan menggunakan sampel perusahaan di luar kategori Indeks Saham Syariah Indonesia. Begitu pula dengan sektor yang digunakan dapat diubah dengan sektor lain seperti manufaktur, pertanian, industri dasar dan kimia, industri barang konsumsi, properti dan sektor lainnya.

Bagi perusahaan go public yang masuk ke dalam Indeks Saham Syariah Indonesia sebaiknya memberikan lebih banyak informasi kegiatan perusahaan yang sesuai dengan aturan indeks ISR, sehingga dapat dijadikan panduan bagi investor muslim dalam menanamkan modalnya di perusahaan. Hal ini akan menambah nilai positif bagi perusahaan untuk menarik minat investor muslim yang menginginkan terpenuhinya kebutuhan material dan spiritual.

\section{DAFTAR PUSTAKA}

Affandi, H., \& Meta Nursita. (2019). Profitabilitas, Likuiditas, Leverage dan Ukuran Perusahaan: Sebuah Analisis Islamic Social Reporting (ISR) pada Perusahaan yang Terdaftar di JII. Majalah Ilmiah BIJAK, 16(1).

Arnel, E., \& Astuti Yuli Setyani. (2018). Pengaruh Pengungkapan Corporate Social Responsibility Dan Kinerja Keuangan Perusahaan Terhadap Return Saham Perusahaan Manufaktur di Bursa Efek Indonesia Tahun 2012-2016. 
Badan Pusat Statistik. (2018). Produk Domestik Bruto Indonesia Triwulanan Tahun 2014-2018. Jakarta: BPS.

Budi, T. S. W. (2010). Pengaruh Pengungkapan CSR dan Kinerja Keuangan Perusahaan Terhadap returm Saham Perusahaan di Indeks LQ45 BEI Periode 2008-2010, 9

Budiyono, I., \& Arum, M. S. D. (2020). Determinants in detecting fraud triangle of financial statements on companies registered in Jakarta Islamic Index (JII) period 2012-2018. Journal of Islamic Accounting and Finance Research, 2(1), 117.

Desiana, F., \& Titin Hartini. (2014). Pengaruh Return On Equity, Earning Per Share dan Price Earning Ratio Terhadap Return Saham Perusahaan Industri Barang Konsumsi di Bursa Efek Indonesia.

Fahmi, I. (2017a). Analisis Kinerja Keuangan. Bandung: Alfabeta.

Fahmi, I. (2017b). Analisis Laporan Keuangan. Bandung: Alfabeta.

Farida, D. N. (2019). Pengungkapan lingkungan dan etika a l qur'an pada perusahaan tambang di indonesia. Maksimum:Meddiaa Akuntansi Universitas Muhamadiyah Semarang, 8(2), 81-92.

Fitriana, D., Andini, R., \& Oemar, A. (2016). Pengaruh Likuiditas, Solvabilitas,Profitabilitas, Aktivitas Dan Kebijakan Dividen Terhadap Return Saham Perusahaan Pertambangan Yang Terdaftar Pada Bei Periode 2007-2013 Dewi. Journal of Accounting, 2(2).

Haniffa, R. (2002). Social Reporting Disclosure: An Islamic Perspective. Indonesian Management \& Accounting Research, 1(2).

Harsono, A. (2015). Analisis Pengaruh Islamic Social Reporting, Dividend Payout Ratio, Price Earning Ratio Terhadap Return Saham Syari'ah pada Perusahaan Go Public di Jakarta Islamic Index Tahun 2010-2012. Universitas Negeri Semarang.

Hartono, J. (2017). Teori Portofolio dan Analisis Investasi. Yogyakarta: BPFEAnggota IKAPI.

Jumingan. (2014). Analisis Laporan Keuangan. Jakarta: PT. Bumi Aksara.

Kasmir. (2016). Analisis Laporan Keuangan. Jakarta: Rajawali Pers.

Mayasari, D. (2019). Pengaruh Laba Akuntansi dan Pengungkapan Islamic Social Reporting (ISR) terhadap Return Saham Syariah yang Terdaftar di JII. Universitas Islam Negeri Raden Intan Lampung.

Namjudin. (2011). Manajemen Keuangan dan Aktualisasi Syar'iyyah Modern. Yogyakarta: ANDI.

Nurmasari, I. (2017). Analisis Current Ratio, Return On Equity, Debt To Equity Ratio Dan Pertumbuhan Pedapatan Berpengaruh Return Saham Pada Perusahaan Pertambangan di BEI 2010-2014. Jurnal Ilmiah Kreatif, 5(1), 112.

Parwati, R. A. D., \& Sudiartha, G. M. (2016). Pengaruh Profitabilitas, Leverage, Likuiditas Dan Penilaian Pasar Tehadap Return Saham Perusahaan Manufaktur. E-Jurnal Manajemen Universitas Udayana, 5(1).

Prasetyoningrum, A. K. (2018). Pengaruh Ukuran Perusahaan, Profitabilitas, Leverage, Efisiensi Biaya dan Umur Perusahaan Terhadap Islamic Social 
Reporting (ISR) pada Perbankan Syariah di Indonesia. MALIA: Journal of Islamic Banking And Finance, 2(2).

Priyonoto, B., Wibowo, A. S., \& Diarsyad, I. (2018). Pengaruh Current Ratio, Debt To Equity Ratio, Return on Equity Terhadap Return Saham Pada Perusahaan Consumer Goods Yang Go Public Di Bursa Efek Indonesia Tahun 2013-2016. Reseachgate.

Purnamasari, L. (2017). Pengaruh Return On Asset dan return On Equity Terhadap Return Saham. E-Journal Universitas PGRI Yogjakarta, 1-13.

Putra, I. B. G. W., \& I Made Karya Utama. (2015). Pengaruh Pengungkapan Corporate Social Responsibility dan Infomasi Laba Akuntansi pada Return Saham. E-Jurnal Akuntansi Universitas Udayana.

Putra, I. M. G. D., \& I Made Dana. (2016). Pengaruh Profitabilitas, Leverage, Likuiditas dan Ukuran Perusahaan Terhadap Return Saham Perusahaan Farmasi di BEI. E-Jurnal Manajemen Unud, 5(11).

Rahayu, R. S., \& Ari Dwi Cahyati. (2015). Faktor-Faktor Yang Mempengaruhi Pengungkapan Corporate Social Responsibility (CSR) Pada Perbankan Syariah. JRAK, Vol. 5(2).

Rahmawati, A. (2017). Pengaruh Return,On Equity (ROE), Debt Ratio (DR), Debt To Equity Ratio (DER), Earning Per Share (EPS) Terhadap Harga Saham (Studi pada perusahaan Food and Beverage yang terdaftar di Bursa Efek Indonesia Periode 2011-2013). E Jurnal Fakultas Ekonomi Universitas Pakuan.

Rizal, M. (2016). Analisis Pengaruh Profitabilitas dan Likuiditas Terhadap Return Saham Syariah dengan Risiko Investasi Sebagai Variabel Intervening ( Studi Empiris pada Perusahaan Tambang yang terdaftar di Daftar Efek Syariah periode 2012-2014 ) The Analysis Effect of Pro. Jurnal Univ Jember.

Rosmiati Tarmizi et al. (2018). Pengaruh Likuiditas dan Profitabilitas Terhadap Return Saham. JURNAL Akuntansi \& Keuangan, 9(1).

Rusmita, S. (2016). Pengaruh Return On Asset dan Corporate Social Responsibility Terhadap Return Saham. Jurnal Audit Dan Akuntansi Universitas Tanjungpura, 5(2).

Sanusi, A. (2011). Metode Penelitian Bisnis. Jakarta: Salemba Empat.

Sulistiyowati, A. (2018). Pengaruh Corporate Social Responsibility (CSR) Terhadap Kinerja Keuangan Perusahaan dan Return Saham.

Susilo, B. (2009). Pasar Modal. Yogyakarta: UPP STIM YKPN.

Thrisye, R. Y., \& Simu, N. (2013). Analisis Pengaruh Rasio Keuangan Terhadap Return Saham Bumn Sektor Pertambangan Periode 2007-2010. Jurnal Ilmiah Akuntansi Dan Bisnis, 8(2), 75-81.

Wardani, S., Hermiyetti, \& Muhammad Yusuf. (2017). Profitabilitas, Likuiditas, Leverage, Arus Kas Operasi Dan Return Saham Syariah Pada Perusahaan Jakarta Islamic Index. Jurnal Riset Akuntansi Dan Perpajakan JRAP, 4(1).

Widarjono, A. (2018). Ekonometrika: Pengantar dan Aplikasinya Disertai Panduan Eviews (Edisi Keli). Yogyakarta: UPP STIM YKPN. 
Elsaputri Dyahayu Fatmawati : Dampak Profitabilitas, Likuiditas dan Pengungkapan ISR

$\overline{\text { Winarno, W. W. (2017). Analisis Ekonometrika dan Statistika dengan Eviews }}$ (Edisi Keli). Yogyakarta: UPP STIM YKPN.

Wulandari, D., Purnomo, H., \& Murniati, W. (2018). Jurnal Riset Akuntansi Jurnal Riset Akuntansi. Jurnal Riset Akuntansi, 1(September), 1-7.

Yuliantari W., N., \& Sujana, I. (2014). Pengaruh Financial Ratio, Firm Size, Dan Cash Flow Operating Terhadap Return Share Perusahaan F\&B. E-Jurnal Akuntansi, 7(3), 547-558. 